\title{
The Effect of Agility Exercises on the COD Speed and Speed in Terms of the Frequency of the Training
}

\author{
Nebahat Eler ${ }^{1, *}$, Serdar Eler ${ }^{2}$ \\ ${ }^{1}$ School of Physical Education and Sport, Bulent Ecevit University, Turkey \\ ${ }^{2}$ Faculty of Sports Sciences, Gazi University, Turkey
}

Copyright $\odot 2018$ by authors, all rights reserved. Authors agree that this article remains permanently open access under the terms of the Creative Commons Attribution License 4.0 International License

\begin{abstract}
The aim of this study is to analyze the effect of agility exercises applied on female students who play handball in school teams on the change of direction (COD) speed and speed in terms of different exercise frequencies for 10 weeks. 75 female students have participated in the study. The first group has been applied agility exercises of 20 minutes during the handball work-out after the warm-up exercises for 5 times a week, the second group was applied these exercises for 3 times a week and the third group was applied these exercises for 2 times a week. Before and after the 10 week agility exercises, the athletes' age, sports age, height, weight, Zigzag test (COD speed) and $20 \mathrm{~m}$ speed test measurements were taken. After the exercises, COD speed and $20 \mathrm{~m}$ speed measurements displayed a significance level of difference in terms of the groups $(p<0,05)$. In terms of the COD speed, the average of the $3^{\text {rd }}$ group is significantly higher than the average of the $1^{\text {st }}$ group. In terms of $20 \mathrm{~m}$ speed, the average of the $1^{\text {st }}$ group is significantly lower than the averages of the $2^{\text {nd }}$ group and the $3^{\text {rd }}$ group and there is no significant difference between the $2^{\text {nd }}$ and $3^{\text {rd }}$ groups. In terms of the COD speed, the decrease in the $1^{\text {st }}$ group is significantly higher than the decrease in the $2^{\text {nd }}$ group and the measurements of the $1^{\text {st }}$ and $2^{\text {nd }}$ groups are significantly higher than the decrease in the $3^{\text {rd }}$ group $(3>2>1)$. In terms of the $20 \mathrm{~m}$ speed measurement, the decrease in the 1st group is significantly higher than the decrease in the other two groups and there is no significant difference between the decrease values of the $2^{\text {nd }}$ and $3^{\text {rd }}$ groups. As a result, frequency in the agility exercises of female children who play handball in this age group is important. Within the scope of yearly planning, giving place to agility exercises in a regular manner 5 times a week each for 20 minutes can be stated to affect speed, agility and COD speed performance which are more important in this sport.
\end{abstract}

Keywords COD, Speed, Handball, Female

\section{Introduction}

Handball is a quick and dynamic branch of sports which requires physical strength. Although both technical skills and tactics have an important role in handball, the advantages of the athletes are higher in number. A great start and sprint skills are required for the quick attacks which are seen quite often during the game. In the throwing movements which are performed by jumping, falling, spinning and bending and in body spoofs, throwing strength and physical characteristics are extremely important [1]. Handball requires a significant strength capacity in terms of throwing, blocking, pushing, spinning and changing speed. It is an exhausting contact sport, in which shooting the ball, blocking, jumping and pushing carry importance. In addition, muscle strength, power and technical-tactical skills are aspects which provide net advantages in handball games [8]. Marques (2009) defines handball as a type of sport which involves continuous explosive sprints, jumps, direction changes, throwing passes and body contact while doing these [15].

Modern handball has become a speedy game, in which the athletes are required to display a superior sportive performance due to its changing rules. The athletes perform numerous and different movements in line with the required tactics within a very short time slice [18]. The basic movement patterns of team sports require athletes to do sudden changes in their body movements and the joints to move in a fast manner and the skill of the athletes in using these maneuvers successfully depends on visual processing, reaction time, perception and other factors [24]. The skill of displaying movements with as much great speed as possible is defined as speed and the skill of changing direction in a speedy manner without losing speed and protecting balance is defined as agility [29]. In other words, agility is the reaction given to a stimulant by the whole body in the shortest time possible by speedily changing direction [23]. In almost all sports branches, moving towards different directions in a speedy and sudden manner and then slowing down involve the 
movement of the whole body. In reality, being able to move to different directions in all types of sports is more important than the sprint speed from a straight line [6]. Agility is one of the most important characteristics which has been developed in strength and fitness programs for team athletes and which needs to be applied regularly [3; $23 ; 29]$. With the purpose of developing agility as required, both general and special exercises are made use of within a specific time period. Within the scope of exercises on speed and agility, special training exercises should be applied in early ages. Children can be given these exercises at the age of 5 to display the strategies used to acquire the suitable motor skills and these characteristics should be continued in particular during the critical development stage between the ages of 9-12 [5]. Mirkov et al. (2010) have stated that agility and coordination are important factors in the future success of athletes aged 11 [17]. During this period, which provides a structure to learn movement models, timing, balance and coordination, planned exercises should be higher in number [2].

However, especially in exercises performed during competitions, strength, endurance and coordination exercises are higher in number. Agility should be performed in a long time slice and with numerous repetitions. In particular in athletes who are in development stage, skill, movements specific to the sports branch and timing should be included regularly in the yearly exercise plan with the purpose of developing these.

The aim of this study is to analyze the effect of agility exercises applied on female students aged 12-14 who play handball in school teams on the characteristics of COD speed and speed in terms of the different exercise frequencies for 10 weeks.

\section{Materials and Methods}

\subsection{Subjects}

75 female students aged 12-14, who play handball in their schools' teams in the city of Ankara have participated in the study (Table 1). Permissions were received from the families and the school administration for the study.
Table 1. Some physical characteristics of the athletes who participated in the study

\begin{tabular}{|c|c|c|c|c|}
\hline & & $\mathrm{N}$ & Ave. & Std. Dev. \\
\hline \multirow{3}{*}{ Sport age (year) } & 1. group & 25 & 3,52 & 0,91 \\
\cline { 2 - 5 } & 2. group & 25 & 3,88 & 1,03 \\
\cline { 2 - 5 } & 3. group & 25 & 3,92 & 0,97 \\
\hline \multirow{4}{*}{ Age (year) } & 1. group & 25 & 12,9 & 0,71 \\
\cline { 2 - 5 } & 2. group & 25 & 12,9 & 0,57 \\
\cline { 2 - 5 } & 3. group & 25 & 12,8 & 0,81 \\
\hline \multirow{3}{*}{ Height (cm) } & 1. group & 25 & 154 & 8,99 \\
\cline { 2 - 5 } & 2. group & 25 & 155 & 7,14 \\
\cline { 2 - 5 } & 3. group & 25 & 155 & 7,11 \\
\hline \multirow{3}{*}{ Weight (kg) } & 1. group & 25 & 46,5 & 10,3 \\
\cline { 2 - 5 } & 2. group & 25 & 47 & 8,66 \\
\cline { 2 - 5 } & 3. group & 25 & 46,4 & 9,52 \\
\hline
\end{tabular}

75 students separated into 3 groups. The groups were assigned without a certain rule. The 1st group was given an agility exercise of 20 minutes for 5 days a week during the handball training after the warm-up exercises; the second group was given an agility exercise of 20 minutes for 3 days a week during the handball training after the warm-up exercises and the third group was given an agility exercise of 20 minutes for 2 days a week during the handball training after the warm-up exercises. Before and after the agility exercises which were performed for 10 weeks [line and limit exercises, skipping back and forth, skipping back and forth with two feet, outward and side skipping scissors movements, 180 degrees spinning movement by skipping, oval line run, triangle line run, double line run, forward, backward, forward-backward run, 180 degree run, funnel drills, exercise stairs drills (single skip, double skip, spot drills (( V drill, Ok drill, M drill)], COD test (Zigzag Test) (Figure 1) and $20 \mathrm{~m}$ speed test measurements were taken.

\subsection{Measurements}

The students' body weight measurements have been taken with the sensitive digital scale whose sensitivity level is $0.1 \mathrm{~kg}$ and their body height measurements have been taken with a height scale with a sensitivity of $0.01 \mathrm{~m}$. 


\section{COD TEST Zigzag Test}

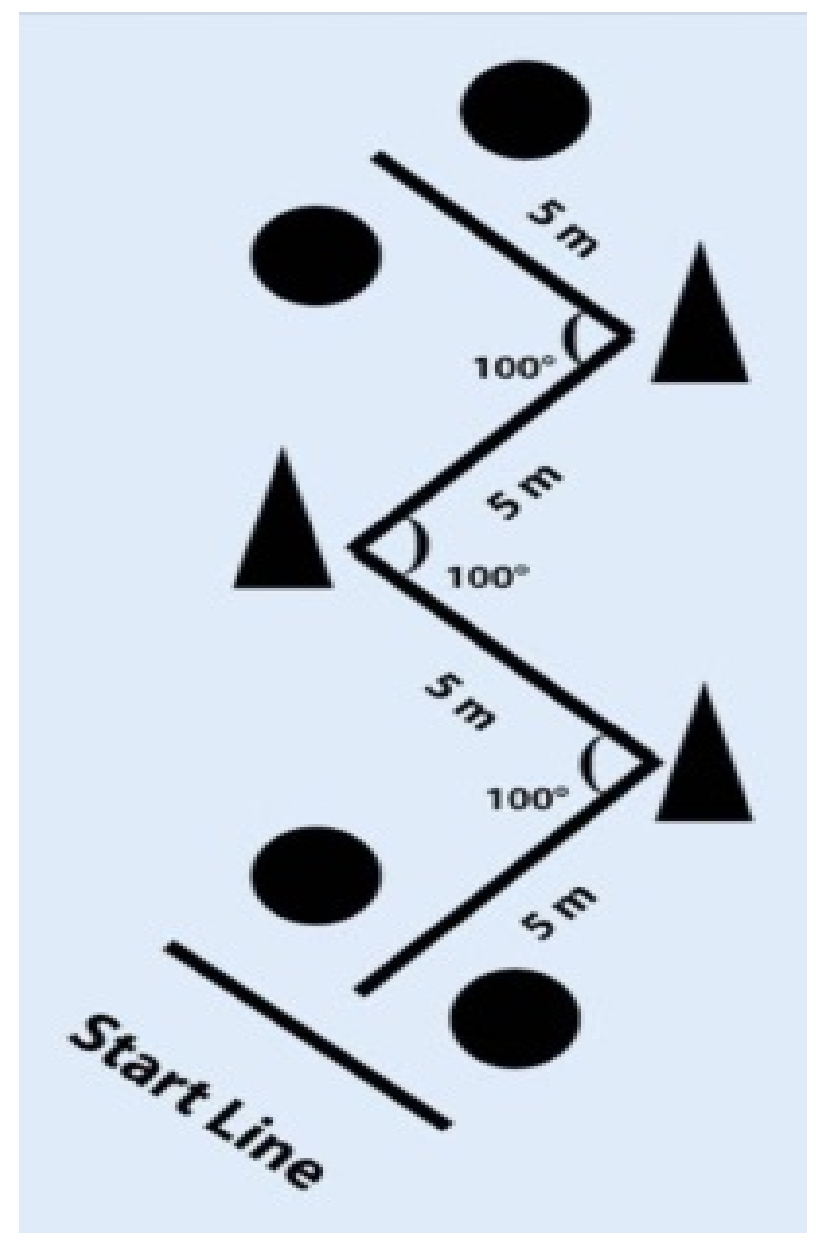

Figure 1. Zigzag Test

The Zigzag Test consists of four 5 meter sections separated by cones placed in $100^{\circ}$ angles, which requires the athletes to slow down and speed up in the fastest manner possible. There are 5 meter intervals between each cone and the total distance is 20 meters. The athlete stars the run with her first feet $0.3 \mathrm{~m}$ behind the start line and in the high position. Two trials have been performed, sufficient rest time has been given between the trials and the best result has been recorded.

\section{$20 \mathrm{~m}$ Speed Test}

Speed has been measured with the $20 \mathrm{~m}$ Speed Test (seconds) and the athletes ran after the start sign was given with maximal speed for 20 meters. The time between start and finish has been determined with the photocell technique (New Test 2000) and the best result has been recorded.

\subsection{Analysis of Data}

In the analysis of data, the SPSS 16 software has been used. The $T$ Test has been used to determine the averages of measurements in the different exercise groups before and after the exercises and to determine whether the difference between these averages were significant or not in the dependent groups; One-Way Variance Analysis has been used to determine the averages of exercise groups in terms of the measurement differences before and after the exercises and to determine whether the differences between these averages were significant or not and the Tukey Test has been used to determine from which group the difference arises.

\section{Results}

The comparison of the changing direction and $20 \mathrm{~m}$ speed measurements obtained before the exercise in terms of the exercise groups does not display a significant difference $(p>0,05)$. In other words, it can be stated that the changing direction and $20 \mathrm{~m}$ measurements of the athletes before the exercise in 3 of the groups is at the same level.

The comparison of COD and $20 \mathrm{~m}$ speed measurements obtained after the exercises in terms of the exercise groups displays a significant difference $(p<0,05)$. In terms of the speed of changing direction, the average of the 3rd group is significantly higher than the average of the 1st group. There is no significant difference between the other groups. In terms of the 20 meter speed measurement, the average of the 1 st group is significantly lower than the averages of the 2nd and 3rd groups and there is no significant difference between the 2 nd and 3 rd groups. 
Table 2. Comparison of the measurement before and after the exercise in terms of the exercise groups

\begin{tabular}{|c|c|c|c|c|c|c|c|}
\hline & & Grup & $\mathrm{N}$ & Ave. & Std. Dev. & $\mathrm{F}$ & $\mathrm{p}$ \\
\hline \multirow{8}{*}{ Before training } & \multirow{4}{*}{ COD dpeed (sn) } & 1. group & 25 & 5,84 & 0,75 & \multirow{4}{*}{0,185} & \multirow{4}{*}{0,831} \\
\hline & & 2. group & 25 & 5,85 & 0,84 & & \\
\hline & & 3. group & 25 & 5,96 & 0,69 & & \\
\hline & & Total & 75 & 5,88 & 0,75 & & \\
\hline & \multirow{4}{*}{$20 \mathrm{~m}$ speed $(\mathrm{sn})$} & 1. group & 25 & 4,14 & 0,44 & \multirow{4}{*}{1,517} & \multirow{4}{*}{0,226} \\
\hline & & 2. group & 25 & 4,34 & 0,67 & & \\
\hline & & 3. group & 25 & 4,39 & 0,48 & & \\
\hline & & Total & 75 & 4,29 & 0,55 & & \\
\hline \multirow{8}{*}{ Aftre training } & \multirow{4}{*}{ COD speed (sn) } & 1. group & 25 & 5,27 & 0,63 & \multirow{4}{*}{3,286} & \multirow{4}{*}{$0,043^{*}$} \\
\hline & & 2. group & 25 & 5,52 & 0,78 & & \\
\hline & & 3. group & 25 & 5,77 & 0,65 & & \\
\hline & & Total & 75 & 5,52 & 0,71 & & \\
\hline & \multirow{4}{*}{$20 \mathrm{~m}$ speed $(\mathrm{sn})$} & 1. group & 25 & 3,89 & 0,33 & \multirow{4}{*}{5,555} & \multirow{4}{*}{$0,006^{*}$} \\
\hline & & 2. group & 25 & 4,23 & 0,64 & & \\
\hline & & 3. group & 25 & 4,34 & 0,48 & & \\
\hline & & Total & 75 & 4,15 & 0,53 & & \\
\hline
\end{tabular}

$*_{\mathrm{p}}<0,05$

According to this, there is a significant difference between the 3 groups in the COD and 20 meter speed measurements before and after the exercises $(p<0,05)$. The changing direction measurements of 3 of the groups before the exercises have displayed a significant decrease compared to the measurements taken after the exercises (Table 2).

Table 3. The averages of the measurements of the groups' COD speed and $20 \mathrm{~m}$ speed before and after the exercises

\begin{tabular}{|c|c|c|c|c|c|c|c|}
\hline & & & $\mathrm{N}$ & Ave. & Std. Dev. & $\mathrm{t}$ & $\mathrm{p}$ \\
\hline \multirow{4}{*}{ 1. group } & \multirow{2}{*}{$\begin{array}{l}\text { COD speed } \\
\text { (sn) }\end{array}$} & Pre-tets & 25 & 5,84 & 0,75 & \multirow{2}{*}{11,58} & \multirow{2}{*}{$0,000^{*}$} \\
\hline & & Pro-test & 25 & 5,27 & 0,63 & & \\
\hline & \multirow{2}{*}{$\begin{array}{l}20 \mathrm{~m} \text { speed } \\
(\mathrm{sn})\end{array}$} & Pre-tets & 25 & 4,14 & 0,44 & \multirow{2}{*}{7,491} & \multirow{2}{*}{$0,000^{*}$} \\
\hline & & Pro-test & 25 & 3,89 & 0,33 & & \\
\hline \multirow{4}{*}{ 2. group } & \multirow{2}{*}{$\begin{array}{l}\text { COD speed } \\
\quad(\mathrm{sn})\end{array}$} & Pre-tets & 25 & 5,85 & 0,84 & \multirow{2}{*}{11,36} & \multirow{2}{*}{$0,000^{*}$} \\
\hline & & Pro-test & 25 & 5,52 & 0,78 & & \\
\hline & \multirow{2}{*}{$\begin{array}{l}20 \text { m sürat } \\
\text { (sn) }\end{array}$} & Pre-tets & 25 & 4,34 & 0,67 & \multirow{2}{*}{5,917} & \multirow{2}{*}{$0,000^{*}$} \\
\hline & & Pro-test & 25 & 4,23 & 0,64 & & \\
\hline \multirow{4}{*}{ 3. group } & \multirow{2}{*}{$\begin{array}{l}\text { COD speed } \\
\text { (sn) }\end{array}$} & Pre-tets & 25 & 5,96 & 0,69 & \multirow{2}{*}{4,909} & \multirow{2}{*}{$0,000^{*}$} \\
\hline & & Pro-test & 25 & 5,77 & 0,65 & & \\
\hline & \multirow{2}{*}{$\begin{array}{l}20 \mathrm{~m} \text { speed } \\
(\mathrm{sn})\end{array}$} & Pre-tets & 25 & 4,39 & 0,48 & \multirow{2}{*}{5,566} & \multirow{2}{*}{$0,000^{*}$} \\
\hline & & Pro-test & 25 & 4,34 & 0,48 & & \\
\hline
\end{tabular}

$* \mathrm{p}<0,001$

Table 4. Averages of measurement differences before and after the exercises according to the exercise groups

\begin{tabular}{|c|c|c|c|c|c|c|}
\hline & & $\mathrm{N}$ & Ave. & Std. Dev. & $\mathrm{F}$ & $\mathrm{p}$ \\
\hline \multirow{4}{*}{ COD speed- difference } & 1. group & 25 & $-0,57$ & 0,24 & \multirow{4}{*}{24,035} & \multirow{4}{*}{$0,000^{*}$} \\
\hline & 2. group & 25 & $-0,33$ & 0,14 & & \\
\hline & 3. group & 25 & $-0,19$ & 0,19 & & \\
\hline & Total & 75 & $-0,36$ & 0,25 & & \\
\hline \multirow{4}{*}{$20 \mathrm{~m}$ speed - difference } & 1. group & 25 & $-0,25$ & 0,17 & \multirow{4}{*}{20,837} & \multirow{4}{*}{$0,000^{*}$} \\
\hline & 2. group & 25 & $-0,11$ & 0,09 & & \\
\hline & 3. group & 25 & $-0,05$ & 0,04 & & \\
\hline & Total & 75 & $-0,14$ & 0,14 & & \\
\hline
\end{tabular}


The differences in the measurements before and after the exercises according to the exercise groups display a significant difference. In terms of the speed of changing direction, the decrease in the 1st group is significantly higher compared to the decrease in the 2nd group and the 1 st and 2nd group measurements are significantly higher than the decrease in the 3 rd group $(3>2>1)$.

\section{Discussion}

In the literature, there are many studies involving different sports branches, ages and gender on agility, speed and COD. The subjects of the studies are the relationship between agility, speed of changing direction and speed [13], the relationship between changing direction and speed $[10 ; 14 ; 1]$, the relationship between vertical jumps and speed $[4 ; 7 ; 8 ; 30]$, the effect of endurance exercises on changing speed [16] (Michael et. al, 2014), the relationship between strength, power, speed and changing direction [19], (Nimphius et al., 2010), the effect of strength on agility and COD [25], the effect of balance, speed and strength on agility [21]. It is known that agility exercises increase performance $[20 ; 22]$. Sporis et al. (2010) have given agility exercises to university students for 3 days a week and have observed an increase in the muscle strength of the athletes at the end of 10 weeks [26]. They have stated that besides endurance, strength, plyometrics and fitness exercises, agility exercises should also be a part of exercise planning to achieve a high level of explosive leg strength and performance [22]. Young et al. (2001) have determined in their study involving the speed and agility exercise program applied to different groups for 6 weeks that, straight sprint speed displayed a significant increase but did not have any effect on agility in the speed group and that the speed of changing direction significantly improved in the agility exercise group [29]. They have reached the conclusion that speed and agility programs should be specific, because the application of classic exercise models may not be advantageous for most sports [9]. In addition, Thomas et al. (2009) has determined in their study that 2 different plyometric exercise techniques improved muscle strength and agility [9]. Walklate et al. (2009) determined as a result of the 4 week short-term sprint and agility exercise applied to badminton athletes that, this exercise has been effective on agility [27]. In our study, the effect of agility exercises applied with different frequencies to female children who play handball on speed and speed of changing direction has been analyzed. It has been estimated that these agility exercise might have an effect on speed and speed of changing direction. However, out hypothesis has been to show the difference in the effects of agility exercises applied with different frequencies ( 5 days, 3 days and 2 days) on speed and speed of changing direction.
The agility exercises in our study have had a positive effect on speed and speed of changing direction in all 3 groups, however it has been seen in our study that doing the agility exercises for 5 days a week for 10 weeks on the speed of changing direction has been more effective than performing these exercises for 3 and 2 days a week and performing them 3 days a week has been more effective than 2 days a week. In terms of speed performance, it has been seen that the agility exercises performed for 5 days a week have been more effective than 3 and 2 days a week. Linear and multi-directional sprint and agility exercises increase performance $[14 ; 20]$. The lack of an exercise program on agility negatively affects performance $[11 ; 12]$.

\section{Conclusions}

As a result, it has been seen that agility exercises have a positive effect on changing direction and speed characteristics and thus on sportive performance. Exercises involving speed and agility should be initiated in the early ages. In this study, the importance of the frequency of agility exercises for female students of this age group who play handball has been underlined. We can suggest that agility which is important for performance should be given place to by coaches and physical education teachers in their annual exercise plans in terms of the development and continuity of speed of changing direction and speed characteristics. In addition, the relationship between the athletes' competition performance and these characteristics can be regularly determined and the frequency of the exercises can be arranged accordingly.

\section{REFERENCES}

[1] Yıldırım, İ., Özdemir V. (2010). Elit Düzey Erkek Hentbol Oyuncularının Antropometrik Özelliklerinin İncelenmesi. Spor ve Performans Araştırmaları Dergisi, 1 (1), 6-13.

[2] Hermassi, S., Chelly, M. S., Tabka, Z., Shephard, R. J., Chamari, K. (2011). Effects Of 8-Week İnseason Upper and Lower Limb Heavy Resistance Training on The Peak Power, Throwing Velocity and Sprint Performance Of Elite Handball Players. Journal of Strength \& Conditioning Research, 25(9), 2424-2433. 10.1519/JSC.0b013e3182030 edb

[3] Marques, M., Van Den Tillaar, R., Gabbett, T., Reis, v. M., González-Badillo, J. J. (2009). Physical Fitness Qualities of Professional Volleyball Players: Determination of Positional Differences. The Journal of Strength \& Conditioning Research, 23(4), 1106-1111.10.1519/JSC.0b $013 \mathrm{e} 31819 \mathrm{~b} 78 \mathrm{c} 4$

[4] Muijen, A. E., Kemper, H.C.G., Van Ingen Schenau, G. J. 
(1991). Throwing Practice with Different Ball Weights: Effects of Throwing Velocity and Muscle Strength İn Female Handball Players. Sports Train Med Rehab 2: 103-13, 1991

[5] Šimonek, J., Horička, P., \& Hianik, J. (2017). The differences in acceleration, maximal speed and agility between soccer, basketball, volleyball and handball players. Journal of Human Sport and Exercise, 12(1), 73-82. https://doi.org/10.14198/jhse.2017.121.06

[6] Young, W. B., Mcdowell, M. H., and Scarlett, B. J. (2001) Specificity of Sprint and Agility Training Methods. The Journal of Strength \& Conditioning Research, 15: 315-319.

[7] Sheppard, J.M. and Young, W. B. (2006). Agility Literature Review: Classifications, Training and Testing. Journal of Sports Sciences, 24: 919-932, 2006. https://doi.org/10.108 $0 / 02640410500457109$

[8] Günay, M. Çeviklik, Masatenisi Çalıştayı, Antalya, 2016.

[9] Brughelli, M, Cronin, J, Levin, G, and Chaouachi, A. (2008). Understanding Change of Direction Ability İn Sport: A Review of Resistance Training Studies. Sports Medicine, 38: 1045-1063 https://doi.org/10.2165/00007256-200838 $120-00007$

[10] Drabik J. Children and Sports Training. How Your Future Champions Should Exercise To Be Healthy, Fit, And Happy. Island Pond. Stadion Publishing Co. 1996.

[11] Mirkov, D. M., Kukolj, M., Ugarkovic, D., Koprivica, V. J., and Jaric, S. (2010). Development of Anthropometric and Physical Performance Profiles of Young Elite Male Soccer Players: A Longitudinal Study. The Journal of Strength \& Conditioning Research, 24: 2677-2682.

10.1519/JSC.0b013e3181e27245

[12] Besier, T. F., Lloyd T.R. (2011). Ackland and JL Cochrane. Anticipatory Effects on Knee Joint Loading during Running and Cutting Maneuvers. Medicine and Science İn Sports and Exercise. 33:1176-1181.

[13] Little, T., \& Williams, A.G. (2005). Specificity of Acceleration, Maximum Speed and Agility İn Professional Soccer Players. Journal of Strength \& Conditioning Research, 19(1), 76-78.

[14] Horıcka, P., Hianık, J., Šımonek, J. (2014). The Relationship between Speed Factors and Agility In Sport Games. Journal of Human Sport \& Exercise, 9(1), 49-58 $10.4100 /$ Jhse. 2014.91 .06

[15] Mann, J. B., Ivey, P. A., Mayhew, J. L., Schumacher, R. M., \& Brechue, W. F. (2016). Relationship between Agility Tests and Short Sprints: Reliability and Smallest Worthwhile Difference in National Collegiate Athletic Association Division-I Football Players. Journal of Strength \& Conditioning Research, 30(4), 893-900.

Https://Doi.Org/10.1519/JSC.0000000000001329

[16] Iş1k Bayraktar The Influences of Speed, Cod Speed and Balance on Reactive Agility Performance in Team Handball 2017, International Journal of Environmental \& Science Education, 3, 451-461 10.12973/Ijese.2017.2140a

[17] Young, W. B., Hawken, M. And Mcdonald, L. 1996. Relationship between Speed, Agility, and Strength Qualities İn Australian Rules football. Strength and
Conditioning Coach, 4(4): 3-6.

[18] Chaouachi, A., Brughelli, M., Chamari, K., Levin, G. T., Ben Abdelkrim, N., Laurencelle, L., and Castagna, C. (2009). Lower Limb Maximal Dynamic Strength and Agility Determinants İn Elite Basketball Players. Journal of Strength \& Conditioning Research, 23: 1570-1577. 10.1519/JSC.0b013e3181a4e7f0

[19] Haj-Sassi, R., Dardouri, W., Gharbi, Z., Chaouachi, A., Mansour, H., Rabhi, A., Mahfoudhi, M. E. (2011). Reliability and Validity of a New Repeated Agility Test as a Measure of Anaerobic and Explosive Power. Journal of Strength \& Conditioning Research, 25: 472-480. 10.1519/JSC.0b013e3182018186

[20] Michael, K., Andre, S., Klaus, W., Dietmar, S. (2014). Long-Term Strength Training Effects on Change-of-Direction Sprint Performance, the Journal of Strength \& Conditioning Research, 28(1), 223-231.10.1519/JSC.0b013e318295644b

[21] Nimphius, S., Michael, M. R., Newton, R. U. (2010). Relationship between Strength, Power, Speed, and Change of Direction Performance of Female Softball Players, the Journal of Strength \& Conditioning Research, 24(4), 885-895. 10.1519/JSC.0b013e3181d4d41d

[22] Spiteri, T., Nimphius, S., Hart, N. H., Specos, C., Sheppard, J. M., R. U. (2014). Contribution of Strength Characteristics To Change of Direction and Agility Performance İn Female Basketball Athletes, The Journal of Strength \& Conditioning Research, 28(9), 2415-2423. 10.1519/JSC.0000000000000547

[23] Sekulic, D., Spasic, M., Mirkov, D., Cavar, M., Sattler, T. (2013). Gender-Specific Influences of Balance, Speed, and Power on Agility Performance, The Journal of Strength \& Conditioning Research, 2017(3), 802-811. Doi: 10.1519/JSC.0b013e 31825c2cb0

[24] Özgür, B. Ö., Demirci, D., Özgür, T., Yazıc1, G. (2016). Futbolcularda Altı Haftalık Sürat Antrenmanının Sürat ve Çeviklik, Üzerine Etkisi, İÜ Spor Bilimleri Dergisi, 6, (4), 1303-1414.

[25] Shapie, M. N. M.and Rohizam, R.N.F.R. (2018). A Case Study: The Effects of Speed, Agility And Quickness (SAQ) Training Program on Hand-Eye Coordination and Dynamic Balance Among Children Journal of Physical Fitness, Medicine \& Treatment İn Sports J Phy Fit Treatment \& Sports1 2(4): 1-6 JPFMTS.MS.ID.555591

[26] Sporiš, G., Milanović, L., Jukić, I., Darija Omrčen, D. and Molinuevo, J. S. (2010). The Effect of Agility Training on Athletic Power Performance Kinesiology, 42 (1), 65-72.

[27] Holmberg, Patrick M MS, CSCS, USAW. (2009). Agility Training for Experienced Athletes: A Dynamical Systems Approach. Strength \& Conditioning Journal, 31(5), 73-78. 10.1519/SSC.0b013e3181b988f

[28] Thomas, K., French, D., Hayes, F. R. (2009). The Effect of Two Plyometric Training Techniques on Muscular Power and Agility in Youth Soccer Players. The Journal of Strength \& Conditioning Research, 23(1), 332-335. 10.1519/JSC.0b013e318183a01a

[29] Walklate, B. M., Brendan J. O’brien, Carl D. Paton, and 
Young, W. (2009). Supplementing Regular Training with Short-Duration Sprint-Agility Trainıng Leads to a Substantial Increase in Repeated Sprint-Agility Performance with National Level Badminton Players. Journal of Strength and Conditioning Research, 23(5), 1477-1481. 10.1519/JSC.0b013e3181b339d9

[30] Kaplan, T., Erkmen, N., Taşkın, H. (2009). The Evaluation of the Running Speed and Agility Performance in
Professional and Amateur Soccer Players, Journal of Strength and Conditioning Research, 23(3), 774-778. 10.1519/JSC.0b013e3181a079ae

[31] Jovanovic, M., Sporis, G., Omrcen, D., Fiorentini F. (2011). Effects of Speed, Agility, Quıckness Training Method on Power Performance İn Elite Soccer Players. Journal of Strength and Conditioning Research, 25(5), 1285-1292. 10.1519/JSC.0b013e3181d67c65 